\title{
UTILIZING GEOGRAPHIC INFORMATION SYSTEM (GIS) FOR DETERMINING NEW LOCATIONS OF POST OFFICE IN NOVI SAD, SERBIA
}

\author{
Milica Radaković \\ Received: November 15, 2017 | Accepted: December 10, 2017
}

\begin{abstract}
Total number of post offices mapped in the city of Novi Sad is 36. If we consider that 221.854 people live in this city (Census from 2011.), it is roughly calculated that one post office covers more than 6000 people. The purpose of this study is to determine new possible locations for post offices in Novi Sad, in order to reduce the time needed to get to the post office. The methods used in the study are Location-Allocation, Service area and the Create Thiessen polygons tools from the software Arc Map 10.1. The rule of Public Enterprise of PTT Communications "Srbija" states that a new post office can be opened only if 15.000 inhabitants cannot reach the nearest post by $1 \mathrm{~km}$ of walk. This criterion helped in recognizing problematic locations in the city. By opening four new post offices in different parts of the city, such as Adice (two), 7. Juli (one) and Vidovdansko naselje (one), the maximum coverage of users is achieved.
\end{abstract}

Keywords: Create Thiessen polygons, Location-Allocation, Service area, Novi Sad, Post office

\section{INTRODUCTION}

\section{The history of post system in Serbia}

The PTT (Postal, Telegraph, and Telephone service) in Serbia has a tradition of over two centuries. From the seventeenth to the half of the nineteenth century there was a Tatar-Mesulan postal system which developed along the Road to Istanbul on the Balkan Peninsula (also known as Road to Tsarigrad, Imperial Road, or Roman Via Militaris). This system was established at the time of the Ottoman Empire (Paunović, 1929).

University of Novi Sad, Faculty of Sciences, Department of Geography, Tourism and Hotel Management, Trg Dositeja Obradovića 3, 21000 Novi Sad, contact: dgt.milica.radakovic@student.pmf.uns.ac.rs 
The Serbian revolution leader, Đorđe Petrović, who fought the independence from the Ottoman Empire, wrote the new Criminal Law in 1807 where he pays attention to the postal system. He points that the letters which had arrived in a village must be given to the farmer, who will forward them to the right recipient. If the farmer keeps the letter to himself, he will be punished by the beating (Živanović, 1922).

After The Danube's first privileged Steamboat Company (Erste Donau-Dampfschiffahrts-Gesellschaft) from Vienna started doing post transportations in 1834, The Danube played an important role for the letters which came from the Central Europe (Mevissen, 2014). Three years later, the process of letter disinfection started in Serbian city Jagodina. The new formed state, Principality of Serbia, wanted to improve the communication system by opening the first post office in Serbia on June 7. 1840 based on the model from Western Europe. The first telegraph was sent from small city of Aleksinac to Belgrade fifteen years later, and the telephone line was introduced in Belgrade in 1883.

Novi Sad, the city in modern-day Republic of Serbia, had a different history because it is placed on the left bank of The Danube. After the Great Turkish War in 1699 it was under the rule of Habsburg Empire, and later Austro-Hungarian Empire (Randelj, 1997). The first post office in the vicinity of Novi Sad was on the other side of The Danube, in Petrovaradin (which is on higher elevation), most likely due to frequent floods and low terrain of the Novi Sad. For centuries, citizens went to Petrovaradin if they wanted to send a letter. Finally, the first post office was built in 1853, and a telephone line in 1892. After the Second World War, Novi Sad had 48 permanent post offices, which is 12 more than today's number (Company profile, 2011).

Today, Serbian post system consists of 1,507 post offices and almost 15.000 employees (Company profile, 2011). Since 2002, the Post of Serbia has developed GIS and has georeferenced 1.000.000 house numbers in all the major towns in Serbia. Also, over 108.000 PACs (Postal Address Code) are mapped by now. The GIS is used to analyze: territorial availability of buildings and customers, planning of advertising material distribution, route planning, address list generation by zones, population density aiming to plan infrastructure capacities, and selection of best location for new facilities construction (Company catalog, 2011).The planning of the post location implies monitoring and quantification of the potential users in order to close, open or allocate the post office. The main criterions of these three options can be sorted into next groups: spatial, economic and functional. Spatial criterion refers to the number of population and the type of settlement being considered. Economic criterion requires the analysis of the business result in comparison with surrounding post offices. The functional criterion is satisfied when spatial, technical, traffic, safety and other necessary requirements are doing well (The plan of post network, 2009). Organizational structure of regional work units is following: sector for sale and marketing, sector for postal network, IT service, sector for economy, sector of protection and safety. The management of improving the post office network is done by employees of postal network service (Rule book about organization and systematization of works, 2015). 


\section{GIS in nowadays location planning}

With the help of technologies such as Geographic Information System (GIS), now it is possible to identify the best location for opening a post office. Such system implies integration, storing, editing, analyzing and displaying multiple geographic information. All populated areas have public service problems, it is a ubiquitous phenomenon which solution requires the engagement of experts from several areas, and for now the best tools are provided by GIS (Church, 2002). Some of the methods used for location planning will be presented in this paper.

Setting up public services to the most optimal locations leads to their maximum usage by the users. It also results in the improvement and acceleration of PTT traffic. GIS can also be used for other public services. For example: a well-chosen location of a school manifests through increasing school attendance; fire department can more quickly respond to fires; better distribution of electricity and water can be made and even lives can be saved if a new health institution is opened (Fredriksson, 2017). The achievement of the maximum coverage of users with as few institutions as possible was first expressed by the mathematical formula by Church and Velle in 1974. The government may be aware of the problem which the citizens have when they are unable to get to the public services, but due to the financial situation, the government will not open new institutions, although coverage of $100 \%$ guarantees greater use of services and therefore, profit. In less populated areas, this problem is solved by moving the service to a more acceptable location, but in a city such as Novi Sad, which is rapidly being built and expanded, opening new institutions appears to be a rational solution.

\section{METHODOLOGY AND MATERIALS}

Several methods were applied to analyze the new potential locations for post office in Novi Sad.

\section{Location-Allocation}

This method was created in the mid-sixties of the last century (Hakimi, 1964; Haki$\mathrm{mi}$, Kuo, 1991). In this paper it presents the tool within the scope of the Network Analyst extension in software Arc Map 10.1. Its launch is disabled if there is no pre-configured network dataset, which in this case represented the streets of Novi Sad. For each street, the length and the time required to travel through it are calculated, taking an average speed of $4 \mathrm{~km} / \mathrm{h}$. In addition to the network dataset, it was necessary to digitize locations of post offices that already exist in the city. Their addresses are downloaded from the Internet (https://www.yellowpages.rs/sr/poste/novi-sad) and then mapped on the ESRI (Environmental Systems Research Institute) World Street Map, which is one of the free built-in base maps of Arc Map 10.1. In this method the post offices are classified as facilities, and a total number of facilities was 36 . Residential objects represent the places from where users start their way to the post office. For the needs of this paper 2600 res- 
idential buildings in Novi Sad have been mapped. The number could have been larger, but in order to preserve the transparency of the map and due to the close proximity of the objects, every third building was mapped, or just a few within the residential block. Residential buildings are classified as demand points, and they are mapped on the same base map as facilities. Under Advanced Settings, the problem type maximize coverage was selected. This option chooses facilities such that all or the greatest amount of demand points are within a specified impedance cutoff which is manually set to be $15 \mathrm{~min}$ utes. This means that users who can reach the post office by walking for maximum 15 minutes are considered to have a good coverage. The final result of this method is a map where the parts of the city that are distant from the post office can easily be recognized.

\section{Create Thiessen polygons}

These polygons have been named after the meteorologist who devised them more than 100 years ago (Thiessen, 1911). Create Thiessen polygons is a tool that can be found within the Proximity Analysis Tools in Arc Map 10.1. This method uses only one information, which is the location of the post office. When the coordinates are entered, the program creates polygons which have the center in each post office. Inside the resulting polygon is any residential unit nearest to that post office. New post offices are most needed in places where several Thiessen polygons are bordered, since housing units on these places have the same distance from different post offices and none is substantially close to them.

\section{Joining the Census 2011 results}

The results of the last population census from 2011 for the city of Novi Sad were requested from the Republic Institute for Statistics. The smallest spatial units of the city which have the available data are local communities. This number of inhabitants for each local community is important to better understand the spatial distribution of needed and existing post offices. All local communities are mapped and population numbers are added to each polygon. The data is overlapped with the Thiessen polygons by a simple function called Join Data and thus the number of people living around every post office is determined. Also, the population density in Thiessen polygons is calculated, but due to confidentiality of data, the exact numbers will not be published in this paper. This data was used as an additional and consultative material necessary to locate a new post office.

\section{Service area analysis}

The service area method is a tool within Network Analyst extension. This method requires: network dataset which are the streets of Novi Sad, the post offices as facilities, and specified impedance. Decision to run another network analyst tool such as service area is justified because such analysis allows implementing the rule of opening new post office set by the Public Enterprise of PTT Communications "Srbija". In a city with popula- 
tion between 120.000 and 300.000 people a new post office can be opened only if 15.000 inhabitants cannot reach the nearest post by $1 \mathrm{~km}$ of walk (The plan of post network, 2009). The impedance is set to be $1 \mathrm{~km}$, and polygon generation not overlapping, which allows polygons to be allocated to the closest facility. The result of this method shows areas and residential blocks in Novi Sad which are further than $1 \mathrm{~km}$ from the post office.

\section{Repeating Location-Allocation and Service area methods}

When all the methods above were displayed on the map, the potential locations which this study requested were obtained. A new shapefile which includes the locations of new post offices was created. Then the first method was repeated by using the same criterion of 15 minutes, and second method by using $1 \mathrm{~km}$ of walk. The repetition of Location-Allocation and Service area is necessary in order to confirm that new locations were sufficiently well-rated.

\section{RESULTS AND DISCUSSION}

\section{The coverage of existing post offices}

The result of the Location-Allocation method is shown in Map 1. Local communities in the city center have almost the maximum coverage based on the described criterion. Some of them are Stari Grad, Dunav, Vera Pavlović, Sonja Marinković, Narodni heroji and Žitni trg (Map 2). Together, these local communities have more than 100.000 inhabitants, which is half the population of the whole city.

On the other side, the same phenomenon of maximum coverage is present in local communities on the periphery of the city. These communities are different from ones in center not only by position, but also by the number of people living in them, and their larger surface. Interestingly, this quantitative difference between center and periphery communities did not result in different coverage rate. The reasons to this are carefully planned positions of the post offices. Šangaj and Salajka, which cover the significant part of the city territory, have the maximum coverage because of their highly concentrated streets and houses around the post office, while actually most of the space in these local communities is uninhabited. The same case has the post office in the Jugovićevo community at the very west of the city.

The rest of the displayed territory of Novi Sad is not so well covered by the post offices. The habitants from residential buildings with no lines connecting them to the post office (Map 1) need more than 15 minutes walk to the nearest post office.

Here are some examples of insignificant coverage. The local community placed on the south west of the map is called Adice. It has a surface comparable to those at the periphery, but unlike them, it is densely populated. Its habitants have the insignificant coverage. The communities called Telep and Klisa have similar problems. Telep is a large part of the Novi Sad and it covers three local communities with 18.000 people. Dense 
street network on a large surface and numerous houses cause low rate of coverage. The post office at Liman 1 is located in the Faculty of Technical Sciences, and thus is mostly used by students. During some crucial parts of the semester the post is too crowded and inefficient. There are only about 4000 registered people living at Liman 1, but the statistics of the Census does not count the number of students at Univeristy of Novi Sad. When taking in consideration this great number of possible post users, the only conclusion is requesting the new post office. Next to the Liman 1 is the Boško Buha community which does not have a post office at all (red color on Map 2). The community of Detelinara has two post offices and it is located between Omladinski pokret and 7. Juli which have none. Together these three communities have over 30.000 habitants. Ivo Andrić and 7. Juli together have the population of 17.000 , and not a single post office.

A post office at the very north of the city covers a small part of its users, so it must be allocated to the south of the Klisa. It seems like a large part of the city between Klisa and the Novi Sad Railway Station is not covered by any post office, but it is an industrial zone with no residential buildings and thus there is no need for new post office.

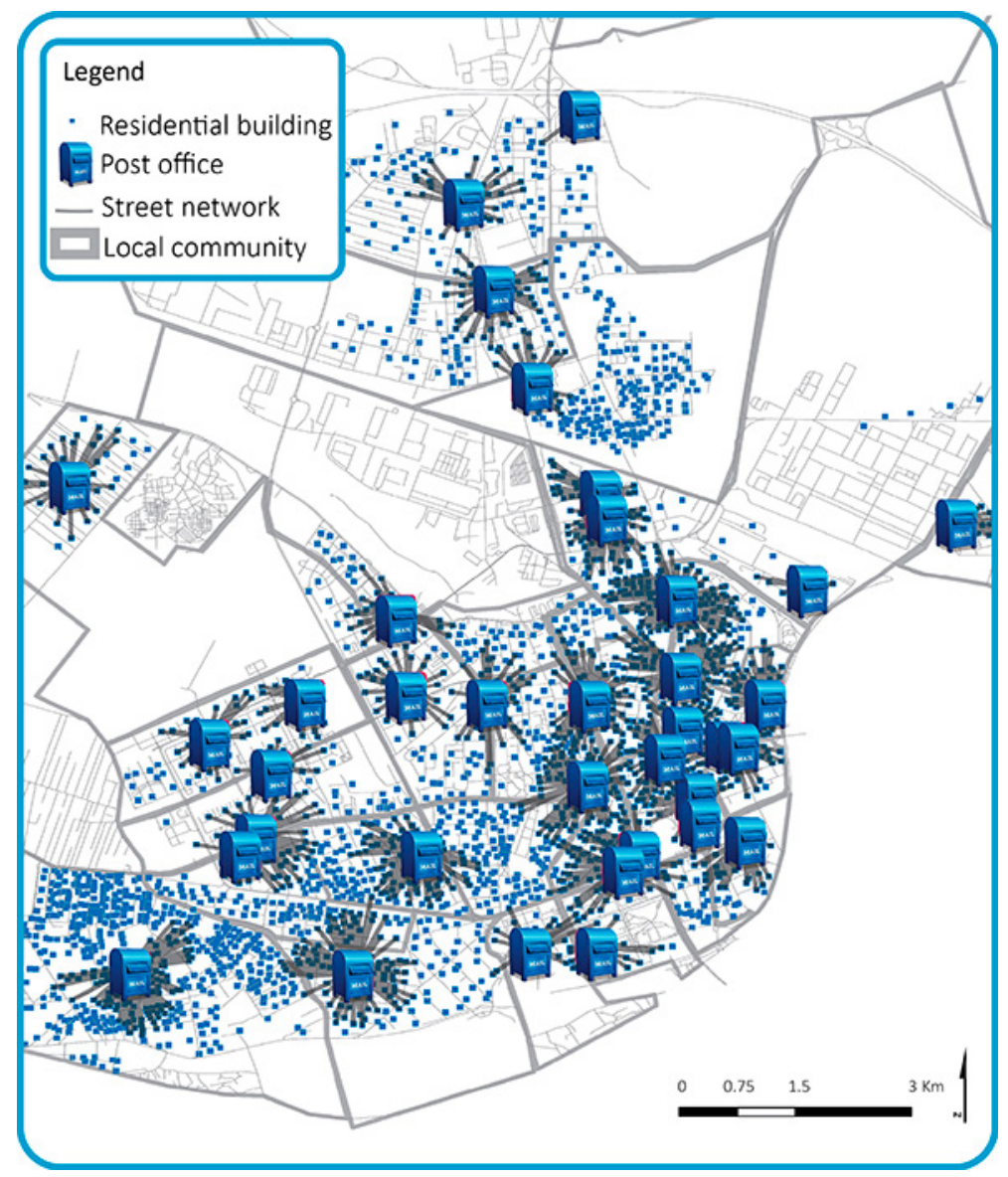

Map 1. Location-Allocation method for post offices in Novi Sad, Serbia 


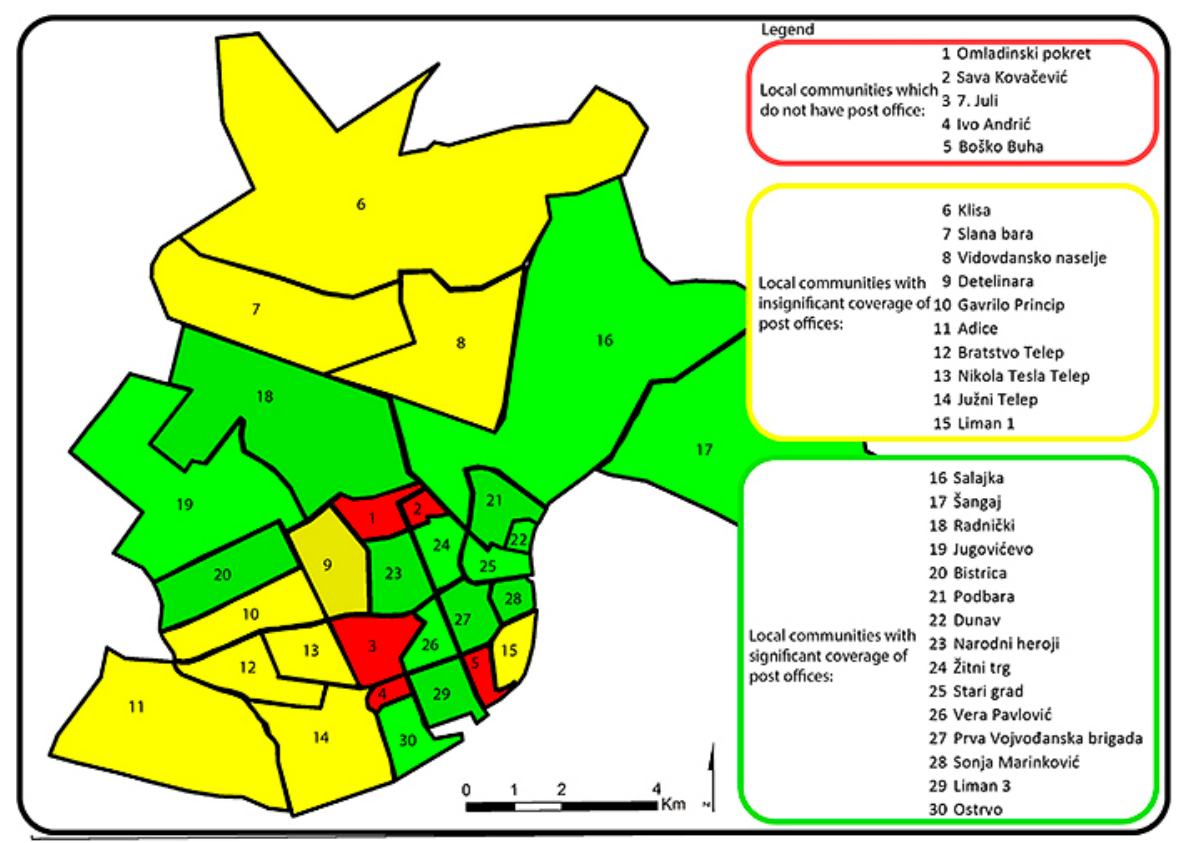

Map 2. Local communities of Novi Sad are sorted by Location-Allocation method into 3 categories: those which do not have post office, those which have the insignificant or the significant coverage

\section{Geometrical area of postal influence}

The Thiessen polygons are shown on Map 3. These polygons are shaped only by equal distance between one and surrounding post offices. They point to a denser network of post offices in the city center and less on the periphery. The red circles on the map represent the problematic areas, or the locations where many polygons are bordered.

Vidovdansko naselje, at the north of Novi Sad has the closest post office on the other side of the Danube-Tisa-Danube Canal, at Salajka community. The next problem is identified between the Telep Nikola Tesla and 7. Juli where the lack of post office leaves many residential blocks uncovered. However, the worst situation is on Adice and Telep which have a channel that passes through and thus separates residential objects from the post office. Due to channel transitions, the users increase the number of minutes required to reach the post office. Adice borders with community Veternik on the west, which does not belong to the city of Novi Sad. However, neither the post office in Veternik is close to Adice, so it certainly does not cover the issue of habitants living at the west of Adice. 


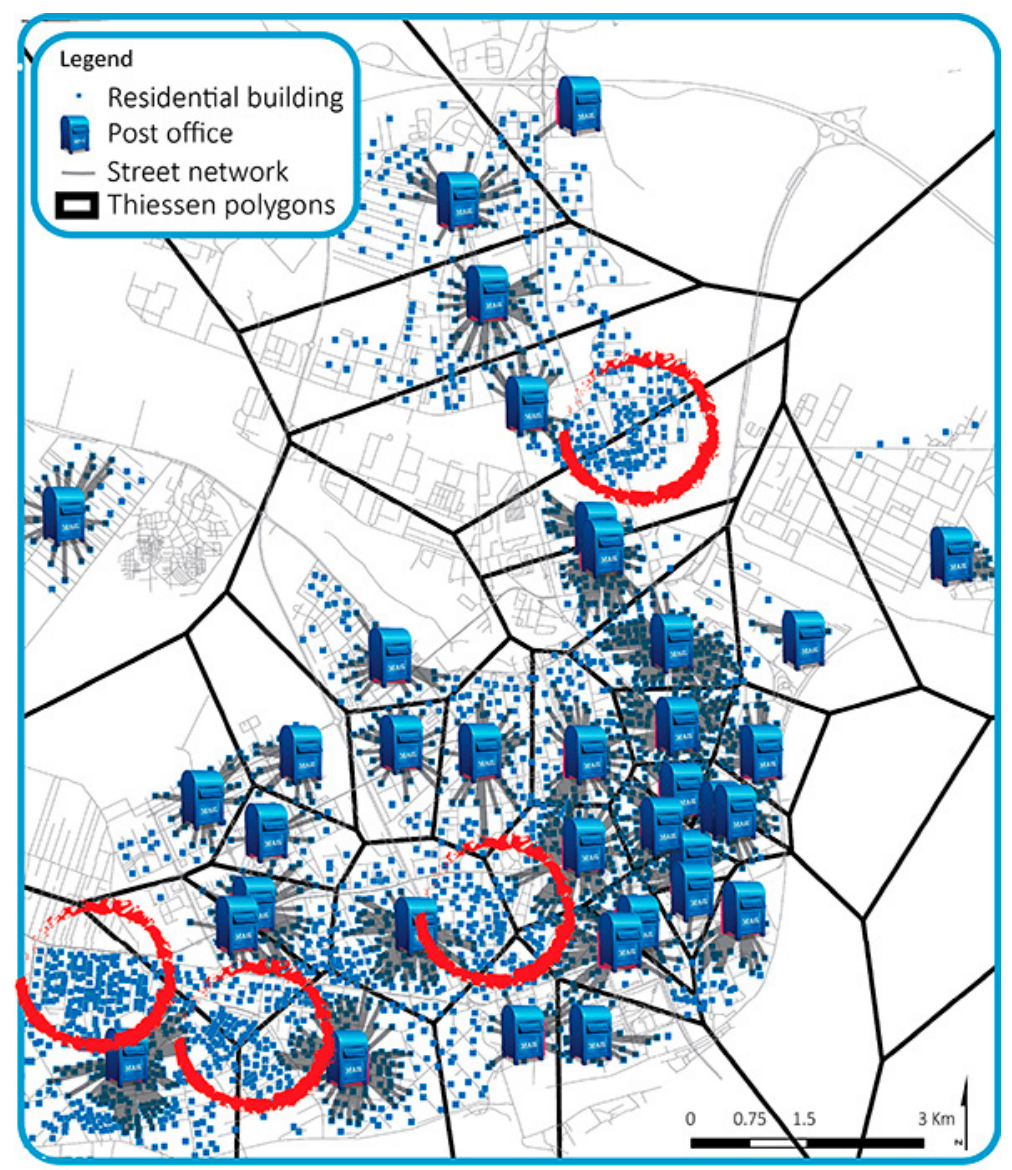

Map 3. Thiessen polygons for post offices and most problematic areas in Novi Sad, Serbia

\section{Potential locations of new post offices}

A proposition for the location of new post offices is displayed on the Map 4. New post is placed on the map based on the results of the previous methods. The software Google Earth Pro was used to find the plots that would be suitable for opening post office (Figure 1). Green envelopes marks on Map 4 are placed on these empty plots. The address of the most northern post office is Prolaz Stevina 7, which is almost the geometric center of the local community Vidovdansko naselje (Figure 1, 1). At Adice there are two post offices, one in Stevan Sindjelic Street 28 (Figure 1,2), and the other at the corner of Branko Copić and Ljubica Ravasi (Figure 1,3). In the center of the map is the post office with the address Cara Dušana 10 (Figure 1,4), which would be located in a large empty ground floor of the building. Map 4 is the result of repeated Location-Allocation method. It can be seen that most of the residential blocks are now covered under a post office. 


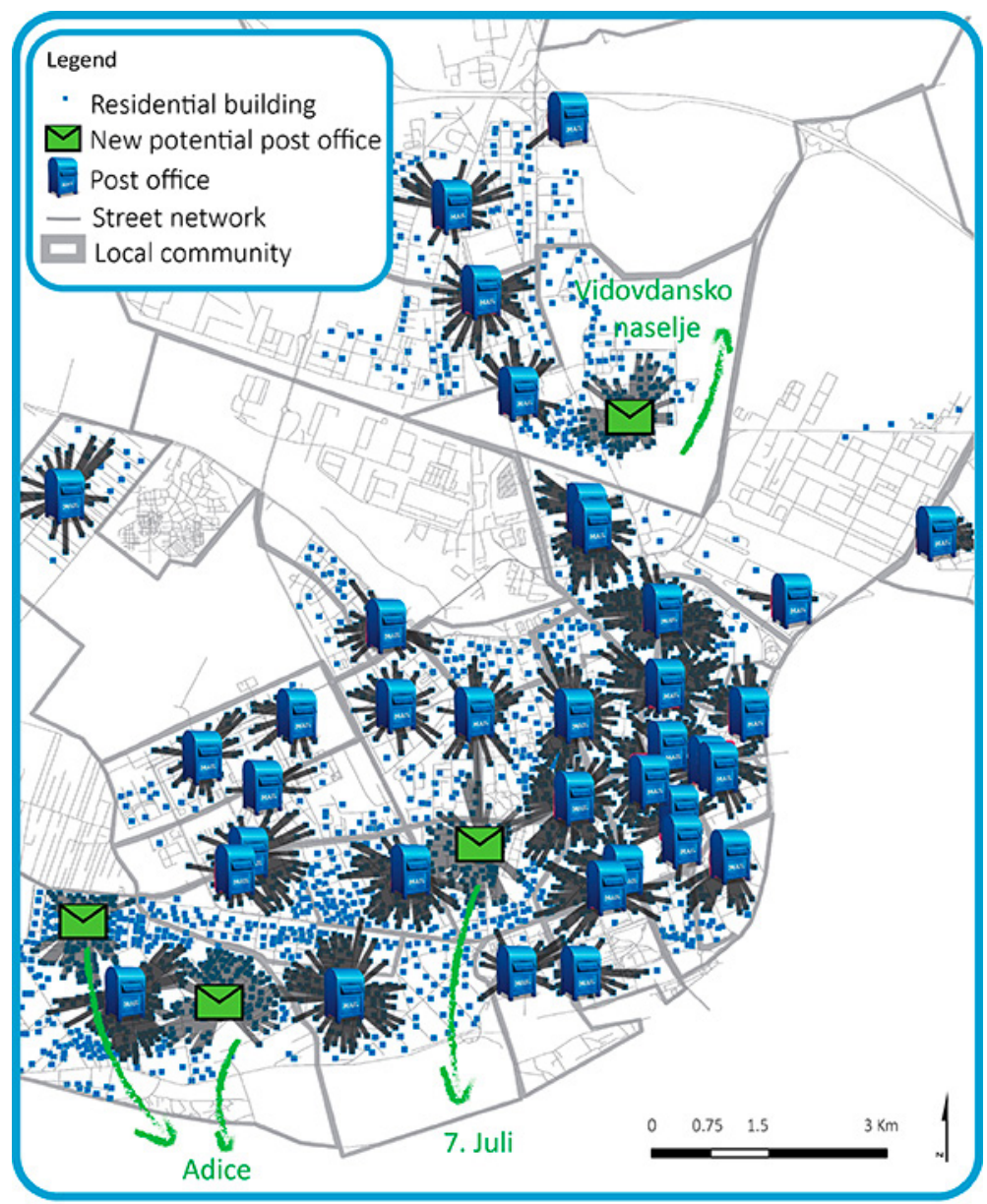

Map 4. The proposition of new locations of post offices in Novi Sad, Serbia

Based on the "Law on Planning and Construction" by Republic of Serbia it is possible to transfer the agricultural or any other land type into land for construction. The fee for changing the purpose of agricultural land into construction land does not exist when constructing the objects of importance for the Republic of Serbia, as well as for the construction of public buildings. In other words, the land development fee is not payable for construction of facilities intended for public use. Once when the land is proclaimed public, it cannot be transformed into private (Law on Planning and Construction 6.2. and 4.1., 2014).

Service area of each post office is shown in Map 5. On the left side is current situation with 36 post offices. The possible locations of new post offices must be at the areas in town which are not colored in green. From these places it is impossible to reach a post office by walking for $1 \mathrm{~km}$. This means that the first condition of the plan for opening a new facility by the PE of PTT Communications "Srbija" is achieved. The second condition is that this area must have at least 15.000 inhabitants. The results of Census 2011 are 

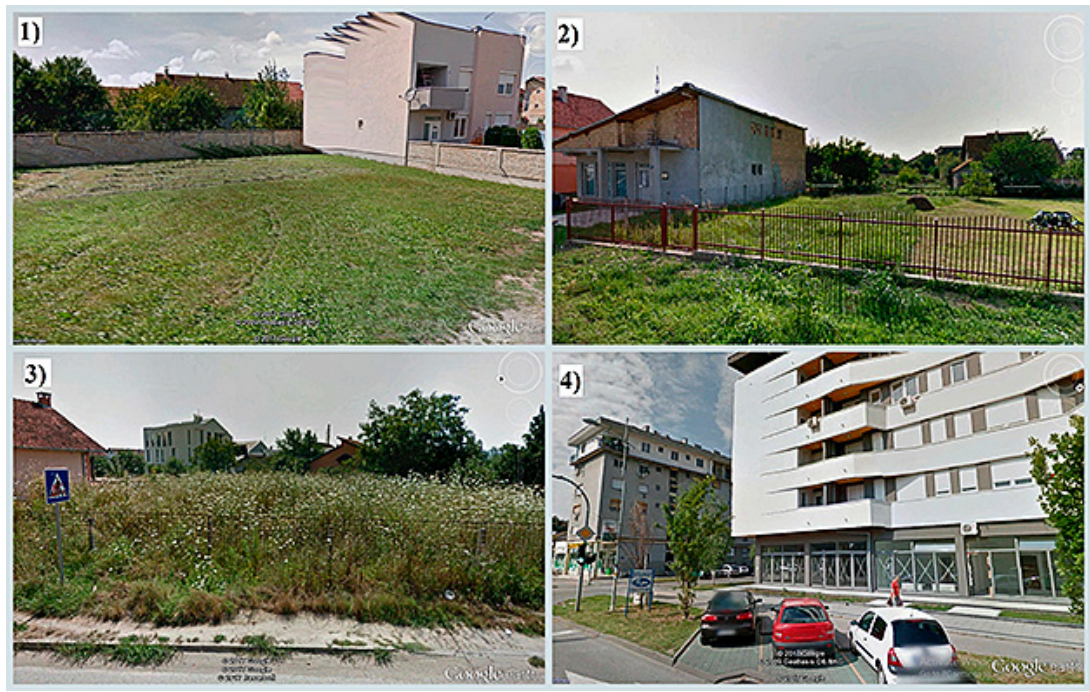

Figure 1. Appropriate plots for placing new post office in Novi Sad

nowadays a bit outdated because seven years have passed and the number of citizens is variable parameter. Regardless of this fact, the areas which are not green on the Map 5 are located in the following local communities: 7. Juli, Detelinara, Adice, Vidovdansko naselje. Detelinara and 7. Juli together have more than 30.000 inhabitants, Adice about 8.000 and Vidovdansko naselje 6.000. This means that local community 7. Juli could be a possible place for opening a new post office. On the right side of Map 5 are the service areas of existing +4 new post offices. In this case, the majority of city surface is covered by post office services.

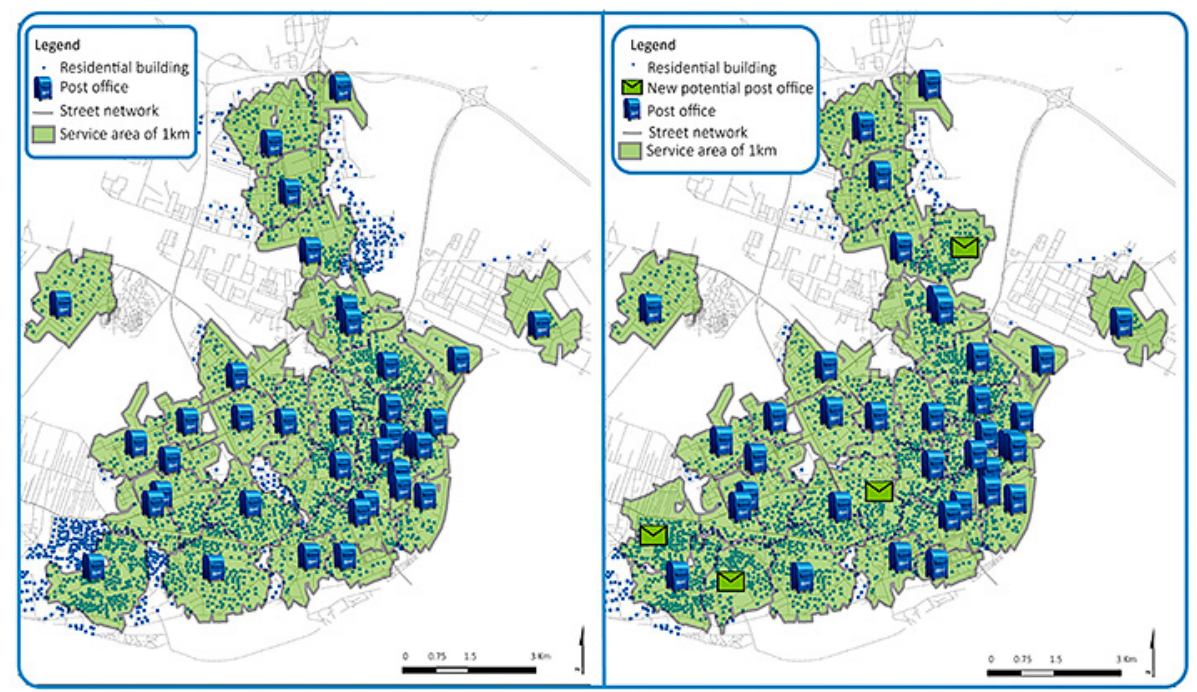

Map 5. Service area of: existing post offices (left) and new potential post offices in Novi Sad 


\section{CONCLUSION}

Today, Serbian post system consists of 1,507 post offices, from which 36 are located in Novi Sad. For purpose of this study coordinates of each post office were mapped in software Arc Map 10.1., as well as surfaces of local communities with population from Cenzus 2011. For each street in Novi Sad, the length and the time required to travel through it are calculated, taking an average speed of $4 \mathrm{~km} / \mathrm{h}$. The methods used in the study are: Location-Allocation, Service area, which are tools in Network anayist extention, and Create Thiessen polygons. Based on all of the methods above, new potential locations for post offices are: two in local community Adice, one in 7. Juli and one in Vidovdansko naselje. The repetition of Location-Allocation and Service area methods was necessary in order to confirm that new locations were sufficiently well-rated.

\section{REFERENCES}

Broj stanovnika po mesnim zajednicama Novi Sad (2011). Beograd: Republički zavod za statistiku

Church, R. and Velle, C. R. (1974). The maximal covering location problem. Papers in regional science, 32(1), 101-118.

Church, R. L. (2002). Geographical information systems and location science. Computers \& Operations Research, 29(6), 541-562.

Company profile (2011). Public Enterprise of PTT Communications "Srbija"

Company catalog (2011). Public Enterprise of PTT Communications "Srbija"

Fredriksson, A. (2017). Location-allocation of public services-Citizen access, transparency and measurement. A method and evidence from Brazil and Sweden. Socio-Economic Planning Sciences, 59, 1-12.

Hakimi, S. L. (1964). Optimum locations of switching centers and the absolute centers and medians of a graph. Operations research, 12(3), 450-459.

Hakimi, S. L. and Kuo, C. C. (1991). On a general network location-production-allocation problem. European Journal of Operational Research, 55(1), 31-45.

Mevissen, R. (2014). Innovation on the Danube and Loyalty in the Habsburg Empire.

Paunović, M. Ž. (1929). Istorija balkanskih pošta. Beograd: Št.Skerlić.

Law on Planning and Construction (2014). ČLAN 6.2. and 4.1.

Randelj, Đ. (1997). Novi Sad - free town. Novi Sad

Rule book about organization and systematization of works (2015). Enterprise of PTT Communications "Srbija"

The plan of post network (2009). Enterprise of PTT Communications "Srbija"

Thiessen, A. H. (1911). Precipitation averages for large areas. Monthly weather review, 39(7), 1082-1089.

World Street Map. Sources: Esri, SeLorme, HERE, USGS, Intermap, iPC, NRCAN, Esri Japan, METi, Esri China (Hong Kong), Esri (Thailand), MapmyIndia, TomTom Živanović, T. (1922). Osnovi krivičnog prava: Opšti deo. Izdavač: Gece Kona. https://www.yellowpages.rs/sr/poste/novi-sad 